\title{
INTRON 2 SPLICE MUTATION AT CYP21 GENE IN PATIENTS WITH CONGENITAL ADRENAL HYPERPLASIA IN THE REPUBLIC OF MACEDONIA
}

\author{
Anastasovska $\mathrm{V}^{1}$, Kocova $\mathrm{M}^{1,2, *}$
}

\begin{abstract}
*Corresponding Author: Mirjana Kocova, Department of Endocrinology and Genetics, University Children's Clinic, Vodnjanska 17, 1000 Skopje, Republic of Macedonia; Tel.: +389-70-242-694; Fax:+389-23-129-027; E-mail: mirjanakocova@yahoo.com
\end{abstract}

\begin{abstract}
Congenital adrenal hyperplasia $(\mathrm{CAH})$ is an autosomal recessive disorder. In $90-95 \%$ of cases it results from mutations in the gene for 21-hydroxylase (CYP21, also termed CYP21A2 and $\mathrm{P} 450 \mathrm{c} 21)$. The IVS-II-656 (C/A>G) mutation leaves $\sim 2.0 \%$ enzyme activity, and comprises $25 \%$ of the classic CYP21 deficiency alleles and $51 \%$ of alleles in the salt-wasting form.

We performed direct molecular diagnosis of the IVS-II mutation in 41 Macedonian patients with different clinical forms of $\mathrm{CAH}$ and 55 of their healthy parents and siblings from 37 unrelated families, using the differential polymerase chain reaction/amplification created restriction site method (PCR/ACRS). The IVS-II mutation was detected in $41.5 \%$ patients $(29.3 \%$ were homozygotes and $12.2 \%$ were heterozygotes). All homozygotes had a severe classical CAH phenotype (of which $91.7 \%$ were salt-wasting and $8.3 \%$ were simple virilizing). Three of the heterozygotes had a salt-wasting (SW) phenotype and were compound heterozygotes. The IVS-II mutation was also found in $30.9 \%$ of the family members $(18.2 \%$ were homozygous

\footnotetext{
${ }^{1}$ Genetic Laboratory, University Children's Clinic, Skopje, Republic of Macedonia

2 Department of Endocrinology and Genetics, University Children's Clinic, Skopje, Republic of Macedonia
}

and $12.7 \%$ were heterozygous) and none had any clinical manifestation. The frequency of the IVS-II mutation (41.5\%) in these subjects was similar to that reported elsewhere.

Key words: Congenital adrenal hyperplasia (CAH), 21-hydroxylase deficiency, CYP21 gene, IVS-II-655 (C/ A>G) mutation.

\section{INTRODUCTION}

Congenital adrenal hyperplasia $(\mathrm{CAH})$ is one of the most common autosomal recessive disorders of adrenal steroidogenesis and characterized by impaired activity of an enzyme required for cortisol biosynthesis [1]. Congenital adrenal hyperplasia due to 21-hydroxylase (CYP21) deficiency is traditionally classed as a classic form with severe enzyme deficiency and prenatal onset of virilization; females present ambiguous genitalia at birth and in both sexes virilization continues postnatally, and a non classical form with mild enzyme deficiency and postnatal onset of premature adrenarche and pubarche in children, virilization in young women, and variable symptoms in young men. The classic form is further divided into the salt-wasting form (SW) with a severe defect in aldosterone biosynthesis, which leads to renal inability to conserve sodium and a simple virilizing (SV) form with apparently normal aldosterone biosynthesis [2-5]. The severe classical form occurs in one in 10,000 
to 15,000 Caucasians [6]. The milder non classical $\mathrm{CAH}$ occurs in $\sim 1$ in 1,700 in the general population [5]. Based on newborn screening data, the carrier frequency of $\mathrm{CAH}$ in the general population is estimated to be 1 in 55 [7].

More than $95 \%$ of cases of CAH are caused by steroid 21-hydroxylase deficiency [6]. The structural gene, CYP21, for the adrenal cytochrome P450 specific for steroid 21-hydroxylation (P450c21) is $3.2 \mathrm{~kb}$ long and contains 10 exons. A CYP21 gene's $2 \mathrm{~kb}$ transcript encodes a polypeptide of 494 or 495 amino acids. This variation results from the polymorphism length in exon 1 , where a tandem repeat number may comprise $(\mathrm{CTG})_{4}$ or $(\mathrm{CTG})_{5}$ [8]. The CYP21 and a pseudogene (CYP21P, CYP21A1P) are located at the 3' terminus of each of the two genes encoding the fourth component of complements $\mathrm{C} 4 \mathrm{~A}$ and $\mathrm{C} 4 \mathrm{~B}$ within the HLA genes, in a DNA segment $\sim 30$ long, in which a tandem duplication probably occurred during evolution [9]. Because of the high homology and tandem-repeat organization, this gene cluster is subject to a high frequency of recombination events, which can lead either to unequal crossover during meiosis, which can produce a wide variety of rearrangements depending on the breakpoint, or large or small gene conversion events that transfer deleterious mutations in the CYP21P gene to the CYP21 gene [10-13]. However, apart from gene deletions and large gene conversions, nine such pseudogenederived mutations account for about $95 \%$ of all affected CYP21 alleles in different ethnic groups, while $\sim 5 \%$ are de novo mutations which did not arise in the pseudogene [6]. There is a good relationship between genotype and clinical disease presentation but a combination of CYP21 mutations can cause different phenotypes [14-16]. The IVSII-656 $(\mathrm{C} / \mathrm{A}>\mathrm{G})$, the $8 \mathrm{bp}$ frameshift deletion at codon 111-113, the thymidine insertion at codon $306(p$.Phe306+t), the nonsense mutation at codon 318 ( $p . G \ln 318 X)$, and the single base substitution at codon 356 (p.Arg356Trp), result in complete inactivation of CYP21, and are found in the severe classical SW form of CAH [17-19]. Here, we present results of direct molecular detection of a CYP21 IVS-II mutation, in which the normal polymorphic $\mathrm{C}$ or $\mathrm{A}$ at nucleotide 655 has been converted to $\mathrm{G}$, in 41 Macedonian patients with different clinical forms of CAH.

\section{MATERIALS AND METHODS}

We studied 41 Macedonian patients (27 girls and 14 boys) with clinical and laboratory signs of $\mathrm{CAH}$ evaluated at the Department of Endocrinology and Genetics, University Children's Clinic, Skopje, Republic of Macedonia, and 55 of their healthy parents and siblings, belonging to 37 unrelated families. There was one patient in 33 families and two patients in four families. Informed consent for the genetic study was obtained from each family. The CAH patients were of mixed ethnicity ( 28 of Macedonian ethnicity, nine of Albanian ethnicity and four Gypsies). All patients had elevated plasma 17-hydroxyprogesterone (17-OHP) and were classified according to standard criteria [2]. Of the 41 patients, $19(46.3 \%)$ had the SW form characterized by extremely elevated 17-OHP levels (up to $75 \mathrm{nmol} / \mathrm{L}$ ) with onset of dehydration and/or shock associated with hyperkalemia and hyponatremia. Females had ambiguous genitalia. The diagnosis was made within 2 months after birth. Four patients $(9.8 \%)$ with SV form at the age 2-14 years were diagnosed due to signs of androgen excess, after corticotropin stimulation. Eighteen patients $(43.9 \%)$ had the LO form characterized in girls by normal external genitalia and in both sexes by precocious pubarche and elevated 17-OHP levels, $60 \mathrm{~min}$. after stimulation [2]. The diagnoisis was made at age 4-17 years.

Molecular Analysis. DNA samples of all subjects were obtained from peripheral blood lymphocytes by the standard proteinase K-phenolchloroform method [20]. Direct molecular detection of the IVS-II-656 mutation was performed by the polymerase chain reaction/amplification created restriction site (PCR/ACRS) method, followed by restriction enzyme digestion [21]. Eight other common pseudogene-derived point mutations: p.Pro30Leu, 8 bp deletion in exon 3 (G110 8 8nt), p.Ile172Asn, exon 6 cluster (p.Ile236Asn, p.Val237Glu, p.Met239Lys), p.Phe306+t, p.Val281Leu, p.Gln318X and p.Arg356Trp were also tested in all subjects (Table 1).

The primary differential PCR amplification of the active CYP21 gene, without contamination from the highly homologous pseudogene sequence, was performed with 20 pmol of each CYP21 specific primer (21BF: 5'-TCG GTG GGA GGG TAC CTG 
Table 1. ACRS detection of mutations in the CYP21gene.

\begin{tabular}{|l|l|c|c|c|c|}
\hline Primer Pair & Mutation Allele & \multicolumn{2}{|c|}{ Restriction Site } & \multicolumn{2}{c|}{ Fragment Size (bp) } \\
\hline & & Natural & Created & Normal & Mutant \\
\hline C1N/C1 & p.Pro30Leu & - & PstI & 195 & $164+31$ \\
\hline C3B/C4A & IVS-II-656 & - & SacI & 115 & $85+30$ \\
\hline C3B/C4A & 8 bp deletion & - & RsaI & 115 & $89+26$ \\
\hline C5/C6 & p.Ile172Asn & - & MseI & 148 & $118+30$ \\
\hline C7D1/C8 & Exon 6 cluster (p.Ile236Asn) & - & MboI & $114+26$ & 140 \\
\hline C7E/C8 & Exon 6 cluster (p.Val237Glu) & - & $T a q I$ & 140 & $116+24$ \\
\hline C7C1/C8 & Exon 6 cluster (p.Met239Lys) & - & $M s e I$ & 140 & $110+30$ \\
\hline C9/C10-1 & p.Val281Leu & $A p a L 1$ & - & $116+101$ & 213 \\
\hline C9A/C9B & p.Phe306+t & - & $M w o I$ & $123+34$ & 157 \\
\hline C11/C12 & p.Gln318X & PstI & - & $146+51$ & 197 \\
\hline C11/C12 & p.Arg356Trp & - & $M s c I$ & 197 & $167+30$ \\
\hline
\end{tabular}

$3.2 \mathrm{~kb}$

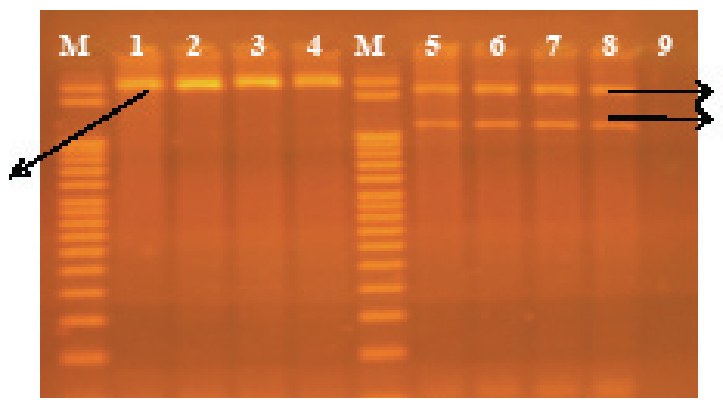

Figure 1. Lanes 1-4: a $3.2 \mathrm{~kb}$ PCR product of the CYP21 gene; lanes 5-8: an EcoRI digestion of the CYP21 PCR product which produced two fragments (1.0 and 2.2 kb); lane 9: blank; M-marker (50 bp).

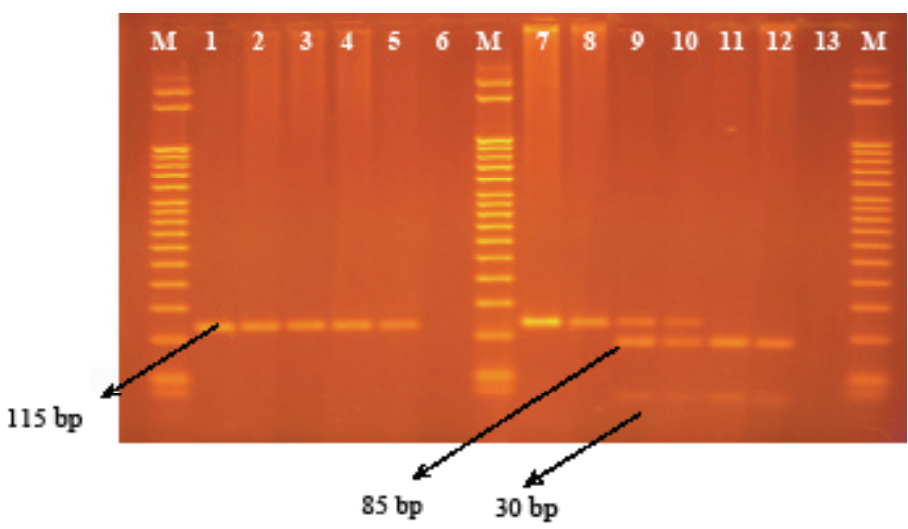

Figure 2. Lanes 1-5: a 115 bp intron 2 PCR product of the CYP21 gene; lanes 7 and 8: (digestion with $\mathrm{SacI}$ restriction enzyme) normal (115bp); lanes 9 and 10: heterozygous (115 bp/85+30bp); lanes 11 and 12: homozygous (85+30bp); lanes 6 and 13: blank; M-marker (50 bp).
AAG-3' and 21BR: 5'-AAT TAA GCC TCA ATC CTC TGC AGC G-3') under the PCR conditions described in Gene Amp XL (Extra Long) PCR Kit (Applied Biosystems, Branchburg, NJ, USA). The EcoRI digestion of the $3.2 \mathrm{~kb}$ PCR product from the CYP21 gene results in two fragments (1.0 and $2.2 \mathrm{~kb}$ ), whereas the pseudogene digested similarly results in three fragments $(0.5,0.6$, and $2.2 \mathrm{~kb})$. This ensured that only the active gene sequence had been amplified and analyzed (Figure1).

The primary PCR product was used as a template for a secondary PCR amplification using the ACRS method with primers specific for detection of the IVS-II mutation (C3B: 5'-TTC ATC AGT TCC CAC CC TCC AGC CCC gA-3' and C4A: 5'-CTT CTT GTG GGC TTT CCA GAG CAG GtA-3'). The secondary ACRS PCR was carried out in a final volume of $50 \mu \mathrm{L}$ containing primary PCR product, $50 \mathrm{pmol}$ of each primer, $200 \mu \mathrm{M}$ of each dNTP, $1,5 \mathrm{mM} \mathrm{MgCl}{ }_{2}$ and $1.25 \mathrm{U}$ Taq DNA polymerase (Ampli Taq Gold; Applied Biosystems) for 30 cycles at $95^{\circ} \mathrm{C}$ for $1 \mathrm{~min} ., 62^{\circ} \mathrm{C}$ for $1 \mathrm{~min}$. and $72^{\circ} \mathrm{C}$ for $2.5 \mathrm{~min}$. A $115 \mathrm{bp}$ PCR product was obtained (Figure 2). The amplified fragments were digested with 5-10 U of a $\mathrm{SacI}$ restriction enzyme at $37^{\circ} \mathrm{C}$ overnight and the digestion products analyzed on $2 \%$ high resolution agarose gel detected by ethidium bromide staining on UV radiation. The mutant allele provides a recognition site for $\mathrm{SacI}$, so that digestion with this enzyme produces two fragments of 85 and 
$30 \mathrm{bp}$. The normal allele contains no restriction site for $\mathrm{SacI}$ (Figure 2). The digestion with the restriction enzyme allowed not only the mutation detection but also determination of the zygosity of the analyzed mutation in an individual.

\section{RESULTS AND DISCUSSION}

The IVS-II mutation was detected in 17 (41.5\%) of the CAH patients. Twelve (29.3\%) were homozygous and five (12.2\%) were heterozygous. All homozygous patients had severe classical CAH phenotype with $91.7 \%$ having the SW phenotype. Although this phenotype is usual in the homozygous state for this mutation [22], one of our homozygous patients displayed the SV phenotype.

Three heterozygous patients with the SW phenotype, were compound heterozygotes having another of the tested mutations (p.Pro30Leu; 8 bp deletion in exon 3 (G110 8 8n)t; p.Ile172Asn; exon 6 cluster (p.Ile236Asn, p.Val237 Glu, p.Met239Lys); p.Phe306+t; p.Val281Leu; p.Gln 318X; p.Arg356Trp). One of the compound heterozygotes had four different mutations: IVS-II, p.Val281Leu, p.Gln $318 X$ and p.Arg356Trp. These complex alleles may have resulted from small or large gene conversions or from multiple mutation events. The second and the third compound heterozygote each had a mutation on another allele, $p \cdot G \ln 318 X$ and p.Arg356Trp, respectively. The genotypes of the three compound heterozygotes and of their parents are presented in Table 2. In two other heterozygotes, one with SW and another with the LO phenotype, no second mutant allele was detected (Table 3 ).

The frequency of the IVS-II mutation allele in our subjects is similar to that reported for other populations. This mutation has a high frequency in many parts of the world, except in some groups of patients in South Europe, and may be a hot-spot [23-25].

The IVS-II mutation was also found in 17 (30.9\%) family members, of whom $10(18.2 \%)$ were homozygotes and seven (12.7\%) were heterozygotes. None had any clinical manifestation.

The IVS-II mutation alters pre-mRNA splicing by activating another acceptor site for the splicing process and thus shifting the reading frame to create premature termination of translation [26]. Comparison of the phenotypic features with the IVS-II genotypes, shows phenotypic heterogeneity extending from classical SW CYP21 deficiency to asymptomatic carrier [26,27].

Table 2. Detected genotypes in the compound CAH heterozygotes and their parents.

\begin{tabular}{|l|l|l|l|}
\hline No & $\begin{array}{l}\text { Compound Heterozygote } \\
\text { Patient }\end{array}$ & Mother's Allele & Father's Allele \\
\hline 1 & $\begin{array}{l}\text { IVS-II/p.Va1281Leu/ } \\
\text { p.Gln318X/p.Arg356Trp }\end{array}$ & $\begin{array}{l}\text { p.Val281Leu/p.Val281Leu/ } \\
\text { p.Gln318X/p.Gln318X/ } \\
\text { p.Arg356Trp }\end{array}$ & IVS-II/ \\
\hline 2 & IVS-II/p.Gln318X & IVS-II/IVS-II & p.Gln318X/ \\
\hline 3 & IVS-II/p.Arg356Trp & IVS-II/IVS-II & p.Arg356Trp/ \\
\hline
\end{tabular}

Table 3. Genotype-phenotype correlation in CAH patients with the detected IVS-II mutation.

\begin{tabular}{|l|c|c|c|c|}
\hline Mutation & $\boldsymbol{n}$ & $\begin{array}{c}\text { Salt-Wasting } \\
(\boldsymbol{n}=\mathbf{1 9})\end{array}$ & $\begin{array}{c}\text { Simple } \\
\text { Virilizing } \\
(\boldsymbol{n}=\mathbf{4})\end{array}$ & $\begin{array}{c}\text { Late Onset } \\
(\boldsymbol{n}=\mathbf{1 8})\end{array}$ \\
\hline IVS-II/IVS-II & 12 & 11 & 1 & - \\
\hline IVS-II/p.Val281Leu/p.Gln318X/p.Arg356Trp & 1 & 1 & - & - \\
\hline IVS-II/p.Gln318X & 1 & 1 & - & - \\
\hline IVS-II/p.Arg356Trp & 1 & 1 & - & - \\
\hline IVS-II/? & 2 & 1 & - & 1 \\
\hline Total & 17 & 15 & 1 & 1 \\
\hline
\end{tabular}


An unusually high frequency of "asymptomatic homozygotes" for a mutation expected to severely compromise CYP21 function has been described [28]. That an apparent homozygosity for the IVSII mutation may result from unequal amplification ("allele dropout") of CYP21 alleles which leads to obscured normal alleles and represent a common diagnostic pitfall of methods employing PCR. For prenatal diagnosis, microsatellite typing could be used as a supplement to CYP21 genotyping so as to resolve ambiguities at nucleotide 656 on intron 2 [28,29]. However, asymptomatic homozygotes for the IVS-II mutation, may be polymorphic for unidentified splice regulatory factors such that the cryptic splice becomes ignored, permitting correct splicing of CYP21 pre-mRNA [28,30]. Since a severe IVS-II mutation almost totally abolishes CYP21 activity, homozygosity for splicing mutation in family members, could be attributed to the tendency of cyto chrome P450 enzymes to be "promiscuous" enzymes that bind many different substrates and catalyze a wide variety of hydroxylations, so that the expression of such an enzyme in the adrenal gland could account for the cryptic CYP21 activity [31].

The observed discordance between genotype and phenotype may result from either the postulated extra adrenal hydroxylase activity or from other factors that modify steroid CYP21 transcription, translation and action. Although some promoter elements important for a CYP2 1 gene transcription are known, and regulatory proteins that affect CYP21 expression have been proposed [32,33], much remains unexplained. Moreover, different receptor numbers or binding affinity for androgens, cortisol or aldo sterone may contribute to the phenotypic variability. Also, the activity of transcription factors and the expression of transport proteins may be individually regulated [34].

Strong genotype-phenotype correlation was observed in all Macedonian CAH patients with the detected IVS-II mutation. However, our results in the other family members confirm that the genotype cannot be completely predictive of phenotype $[22,35]$.

\section{REFERENCES}

1. Speiser PW, White PC. Congenital adrenal hyperplasia. N Engl J Med 2003; 349(8): 776-788.

2. New MI, Lorenzen F, Lerner AJ, Kohn B, Oberfield SE, Pollack MS, Dupont B, Storner E, Levy DJ, Pang S, Levine LS. Genotyping steroid 21-hydroxylase deficiency: Hormonal reference data. J Clin Endocrinol Metab 1983; 57(2): 320326.

3. Miller WL, Morel Y. The molecular genetics of 21-hydroxylase deficiency. Annu Rev Genet 1989; 23:371-393.

4. Speiser PW, New MI, While PC. Molecular genetic analysis of nonclassic steroid 21-hydroxylase deficiency associated with HLA-B14,DR1. N Engl J Med 1988; 319(1): 19-23.

5. Speiser PW, Dupont B, Rubinstein P, Piazza A, Kastelan A. New MI. High frequency of nonclassical steroid 21-hydroxylase deficiency. Am J Hum Genet 1985; 37(4): 650-667.

6. White PC, Speiser PW. Congenital adrenal hyperplasia due to 21-hydroxylase deficiency. Endocrinol Rev 2000; 21(3): 245-291.

7. Baumgartner-Parzer SM, Nowotny P, Heinze G, Waldhäusl W, Vierhapper H. Carrier frequency of congenital adrenal hyperplasia (21-hydroxylase deficiency) in a Middle European population. J Clin Endocrinol Metab 2005; 90(2): 775-778.

8. Strachan T. Molecular patology of 21-hydroxylase deficiency. J Inher Metab Dis 1994; 17(4): 430-441.

9 Fitness J, Dixit N, Webster D, Torresani T, Pergolizzi R, Speiser PW, Day DJ. Genotyping og CYP21, linked chromosome 6p markers, and a sexspecific gene in neonatal screening for congenital adrenal hyperplasia. J Clin Endocrinol Metab 1999; 84(3): 960-966.

10. White PC, Tusie-Luna MT, New MI, Speiser PW. Mutations in steroid 21-hydroxylase (CYP21). Hum Mutat 1994; 3(4): 373-378.

11. Higashi Y, Yoshioka H, Yamane M, Gotoh O, Fujii-Kuriyama Y. Complete nucleotide sequence of two steroid 21-hydroxylase genes tandemly arranged in human chromosome: a pseudogene and a genuine gene. Proc Natl Acad Sci USA 1986; 83(9): 2841-2845.

12. Tusié-Luna MT, White PC. Gene conversion and unequal crossovers between CYP21 (steroid 
21-hydroxylase gene) and CYP21P involve different mechanisms. Proc Natl Acad Sci USA 1995; 92(23): 10796-10800.

13. White PC, New MI, Dupont B. Structure of the human steroid 21-hydroxylase gene. Proc Natl Acad Sci USA 1986; 83(14): 5111-5115.

14. Jaaskelainen J, Levo A, Voutilainen R, Partanen J. Population-wide evaluation of disease manifestation in relation to molecular genotype in steroid 21-hydroxylase (CYP21) deficiency: good correlation in well defined population. J Clin Endocrinol Metab 1997; 82(10): 3293-3297.

15. Krone N, Braun A, Rosher AA, Knorr D, Schwarz HP. Predicting phenotype in steroid 21-hydroxylase deficiency? Comprehensive genotyping in 155 unrelated, well defined patients from southern Germany. J Clin Endocrinol Metab 2000; 85(3): 1059-1065.

16. Rosha RO, Billerbeck AEC, Pinto EM, Melo KFS, Lin CJ, Longui CA, Mendoca BB, Bachega TASS. The degree of external genitalia virilization in girls with 21-hydroxylase deficiency appears to be influenced by the CAG repeats in the androghen receptor gene. Clin Endocrinol 2008; 68(2): 226-232.

17. Fardella CE, Poggi H, Pineda P, Soto J, Torrealba I, Cattani A, Oestreicher E, Foradori A. Salt-wasting congenital adrenal hyperplasia: detection of mutations in CYP21B gene in a Chilean population. J Clinic Endocrinol Metab 1998; 83 (9): 3357-3360.

18. Mornet E, Crété P, Kuttenn F, Raux-Demay MCh, Boué J, White PC, Boué A. Distribution of deletions and seven point mutations on CYP21B genes in three clinical forms of steroid 21-hydroxylase deficiency. Am J Hum Genet 1991; 48(1): 79-88.

19. Arlt W, Walker EA, Draper N, Ivison HE, Ride JP, Hammer F, Chalder SM, BoruckaMankiewicz M, Hauffe BP, Malunowicz EM, Stewart PM, Shackleton CHL. Congenital adrenal hyperplasia caused by mutant $\mathrm{P} 450$ oxidoreductase and human androgen synthesis: analytical study. Lancet 2004; 363(9427): 2128-2135.

20. Efremov GD, Dimovski AJ, PlaseskaKaranfilska D, Simjanovska L, Sukarova E, Koceva S. Laboratory Manual, 3rd ed. Nucleic Acid Based Methods in Human and Veterinerary Medicine. ICGEB Affiliated Center. Skopje, Republic of Macedonia, 1999.
21. Lee HH, Chao HT, Ng HT, Choo KB. Direct molecular diagnosis of CYP21 mutations in congenital adrenal hyperplasia. J Med Genet 1996; 33(5): 371-375.

22. Wedell A. Molecular genetics of congenital adrenal hyperplasia (21-hydroxylase deficiency): implication for diagnosis, prognosis ant treatment. Acta Pediatr 1998; 87(2): 159-164.

23. Wedell A, Thilen A, Ritzen EM, Stengler B, Luthman H. Mutational spectrum of the steroid 21-hydroxylase gene in Sweden: implications for genetic diagnosis and association with disease manifestations. J Clin Endocrinol Metab 1994; 78(5): 1145-1152.

24. Ramazani A, Kahrizi K, Razaghiazar M, Mahdieh N, Koppens P. The frequency of eight common point mutations in CYP21 gene in Iranian patients with congenital adrenal hyperplasia. Iran Biomed J 2008; 12(1): 49-53.

25. Dolžan V, Sólyom J, Fekete G, Kovács J, Rakosnikova V, Voltava F, Lebl J, Pribilincova Z, Baumgartner-Parzer SM, Riedl S, Waldhauser F, Frish H, Stopar-Obreza M, Kržišnik C. Battelino T. Mutational spectrum of steroid 21-hydroxylase and the genotype-phenotype association in the Middle European patients with congenital adrenal hyperplasia. Eur J Endocrinol 2005; 153(1): 99106.

26. Witchel SF, BhamidipatiDK, Hoffman EP, Cohen JB. Phenotypic heterogeneity associated with the splicing mutation in congenital adrenal hyperplasia due to 21-hydroxylase deficiency. J Clin Endocrinol Metab 1996; 81(11): 40814088 .

27. Speiser PW, Dupont J, Zhu D, Serrat J, Buegeleisen M, Tusie-Luna M-T. Lesser M, New MI, White PC. Disease expression and molecular genotype in congenital adrenal hyperplasia due to 21-hydroxylase deficiency. J Clin Invest 1992; 90(2): 584-595.

28. Higashi Y, Tanae A, Inoue H, Hiromasa T, Fujii-Kuriyama Y. Aberrant splicing and missence mutations cause steroid 21-hydroxylase [P-450(C21)] deficiency in humans: Possible gene conversion products. Proc Natl Acad Sci USA 1988; 85(20): 7486-7490.

29. Day DJ, Speiser PhW, Schulze E, Bettendorf M, Fitness J, Barany F, White PC. Identification of non-amplifying CYP21 genes when using PCR- 
based diagnosis of 21-hydroxylase deficiency in congenital adrenal hyperplasia $(\mathrm{CAH})$ affected pedigrees. Hum Molec Genet 1996; 5(12): 20392048.

30. Dolžan V, Stopar-Obreza M, Žerjav-Tanšek M, Breskvar K, Kržišnik C, Battelino T. Mutational spectrum of congenital adrenal hyperplasia in Slovenian patients: a novel Ala15Thr mutation and Pro30Leu within a larger gene conversion associated with a severe form of the disease. Eur J Endocrinol 2003; 149(2): 137-144.

31. Miller WL. Congenital lipoid adrenal hyperplasia: the human gene knockout for the steroidogenic acute regulatory protein. J Molec Endocrinol 1997; 19(3): 227-240.

32. Rice DA, Kronenberg MS, Mouw AR, Aitken LD, Franklin A, Schimmer BP, Parker KL. Multiple regulatory elements determine adrenocortical expression of steroid 21-hydroxylase. J Biol Chem 1990; 265(14): 8052-8058.

33. Donohoue PA, Collins MM. The human complement $\mathrm{C} 4 \mathrm{~B} /$ steroid 21-hydroxylase (CYP21) and complement $\mathrm{C} 4 \mathrm{~A} / 21$-hydroxylase pseudogene (CYP21P) intergenic sequences: comparasion and identification of possible regulatory elements. Biochem Biophys Res Commun 1992; 186(1): 256262.

34. Gomes LG, Huang N, Agrawal V, Mendonca BB, Bachega TASS, Miller WL. The common P450 oxidoreductase variant $\mathrm{A} 503 \mathrm{~V}$ is not a modifier gene for 21-hydroxylase deficiency. J Clin Endocrinol Metab 2008; 93(7): 2913-2916.

35. Wilson RC, Mercado AB, Cheng KC, New MI. Steroid 21-hydroxylase deficiency: Genotype may not predict phenotype. J Clin Endocrinol Metab 1995; 80(8): 2322-2329. 